\title{
HUMAN RIGHTS SITUATION \\ IN THE OCCUPIED PALESTINIAN \\ TERRITORY
}

[Con motivo de los acontecimientos de Oriente Medio, el Consejo de Derechos Humanos de la ONU adoptó una resolución el 5 de julio de 2006.

México decidió abstenerse (junto con Camerún y la República de Corea). El resultado de la votación refleja una clara división entre los países desarrollados occidentales y Japón, que apoyaron a Israel y votaron en contra (11 Estados votaron en contra: Alemania, Canadá, Finlandia, Francia, Holanda, Japón, Polonia, Reino Unido de la Gran Bretaña, República Checa, Rumania, Ucrania), lo que significó ser la minoría; frente a la mayoría de países subdesarrollados que votaron a favor de la resolución (29 Estados votaron a favor, entre los que sobresalen países del continente americano como Argentina, Brasil, Ecuador, Cuba, Guatemala, Perú y Uruguay).

Si bien México expresó las razones de su voto, no deja de manifestarse una ambigüedad incómoda e inútil que, al parecer, no queda bien con nadie.

A continuación reproducimos la resolución y la postura de México.*]

[* Manuel Becerra Ramírez.] 
HUMAN RIGHTS COUNCIL

First special session

5 July 2006

ALGERIA, BAHRAIN, CUBA, EGYPT,* INDONESIA, JORDAN, LEBANON, MALAYSIA, MOROCCO, PAKISTAN (ON BEHALF OF THE ORGANIZATION OF THE ISLAMIC CONFERENCE), SAUDI ARABIA, SUDAN, * SYRIAN ARAB REPUBLIC, * TUNISIA (ON BEHALF OF THE GROUP OF ARAB STATES), UNITED ARAB EMIRATES:* DRAFT RESOLUTION

\section{HUMAN RIGHTS SITUATION IN THE OCCUPIED PALESTINIAN TERRITORY}

The Human Rights Council,

Guided by the principles and objectives of the Charter of the United Nations, the Universal Declaration of Human Rights, and the International Covenants on Human Rights,

Affirming the applicability of the Geneva Convention relative to the Protection of Civil Persons in Time of War, of 12 August 1949, to the Occupied Palestinian Territory, including East Jerusalem, and to other occupied Arab territories,

Expressing deep concern at the breaches by Israel, the occupying Power, of international humanitarian law and human rights law in the Occupied Palestinian Territory, including the arbitrary arrest of Palestinian ministers, members of the Palestinian Legislative Council and other officials, as well as the arbitrary arrest of other civilians, the military attacks against Palestinian ministries, including the office of the Premier and the destruction of Palestinian infrastructure, including water networks, power plants and bridges,

1. Expresses grave concern at the violations of the human rights of the Palestinian people caused by the Israeli occupation, including the current extensive Israeli military operations against Palestinians in the Occupied Palestinian Territory;

2. Demands that Israel, the occupying Power, end its military operations in the Occupied Palestinian Territory, abide scrupulously by the provisions of international humanitarian law and human rights law, and refrain from imposing collective punishment on Palestinian civilians;

* Non-member States of the Human Rights Council. 
3. Expresses grave concern at the detrimental impact of the current Israeli military operation on the already deteriorating humanitarian conditions of the Palestinian people;

4. Urges Israel, the occupying Power, to immediately release the arrested Palestinian ministers, members of the Palestinian Legislative Council and other officials, as well as all other arrested Palestinian civilians;

4 bis. Urges all concerned parties to respect the rules of international humanitarian law, to refrain from violence against the civilian population and to treat under all circumstances all detained combatants and civilians in accordance with the Geneva Conventions;

5. Decides to dispatch an urgent fact finding mission headed by the Special Rapporteur on the situation of human rights in the Occupied Palestinian Territories;

6. Calls for a negotiated solution to the current crisis.

\section{EXPLICACIÓN DEL VOTO DE MÉXICO}

El gobierno de México hubiera preferido un texto equilibrado en el que se hiciera un señalamiento al agravamiento de la crisis entre Israel y Palestina y la obligación de todos los actores de respetar cabalmente las disposiciones del derecho internacional humanitario y de derechos humanos.

Es urgente poner un alto a todas las violaciones de estos derechos, incluyendo la destrucción de infraestructura básica en la región de Gaza y la detención de miembros del gobierno palestino, así como el secuestro del soldado israelí y los ataques a población civil israelí desde Gaza.

México reafirma su convicción de que la solución del conflicto sólo podrá alcanzarse por medios pacíficos, incluyendo el diálogo y la negociación directa entre las partes. Asimismo, manifestamos nuestra preocupación por el deterioro en la zona y la escalada de violencia en los últimos días, destacando la importancia de proteger a la población civil inocente, y garantizándole el acceso a los servicios básicos tales como agua, alimentos y electricidad.

Hacemos votos para que Israel y la Autoridad Nacional Palestina logren crear las condiciones necesarias a través del diálogo para detener la violencia y reanudar el proceso de paz.

El consejo debe tener la capacidad de tomar medidas para evitar el escalamiento de situaciones o emergencias relativas a violaciones a los derechos humanos, privilegiando el diálogo y la concertación. El ideal será siempre prevenir las violaciones y no sólo conformarse con denunciarlas. 
México apoya una visita por parte del relator especial a la región con el fin de elaborar un informe con recomendaciones y observaciones sobre la situación de los derechos humanos en la zona, y espera que las condiciones necesarias para que dicha visita pueda realizarse en un breve plazo, se cumplan a cabalidad.

6 de julio de 2006 